\title{
California farmers adapt mandated marketing programs to the 21st century
}

by Hoy Carman

Mandated marketing programs are an important component of California agriculture. The state's 63 marketing programs cover commodities that accounted for two-thirds of the total value of California agricultural output in 2004. California farmers have recently paid annual assessments totaling more than \$226 million to support advertising, promotion, research and inspection programs. Marketing programs have evolved from emphasizing supply controls in the 1930s and 1940s to the current focus on generic advertising and promotion, food safety inspection, health and nutrition research, and market information.

alifornia's government-mandated marketing programs covered commodities accounting for over $\$ 21.18$ billion $(66 \%)$ of California crop and livestock production in 2004. While the framework for these marketing programs is set by legislation, the specific provisions are proposed by producers, approved by the secretary of agriculture (marketing orders and agreements) or the legislature and governor (commissions and councils), and enacted by a supermajority vote of producers covered by the program's provisions.

Once enacted, all producers are subject to program provisions and all must pay assessments to cover program costs, with enforcement based on the police and taxing powers of government. This paper reviews the nature, importance, extent and changing use of common program provisions for mandated marketing programs utilized by California producers, and the development of new research, promotion and information initiatives. Not included in the data tables are California producers' participation in federal promotion programs, commonly referred to as national

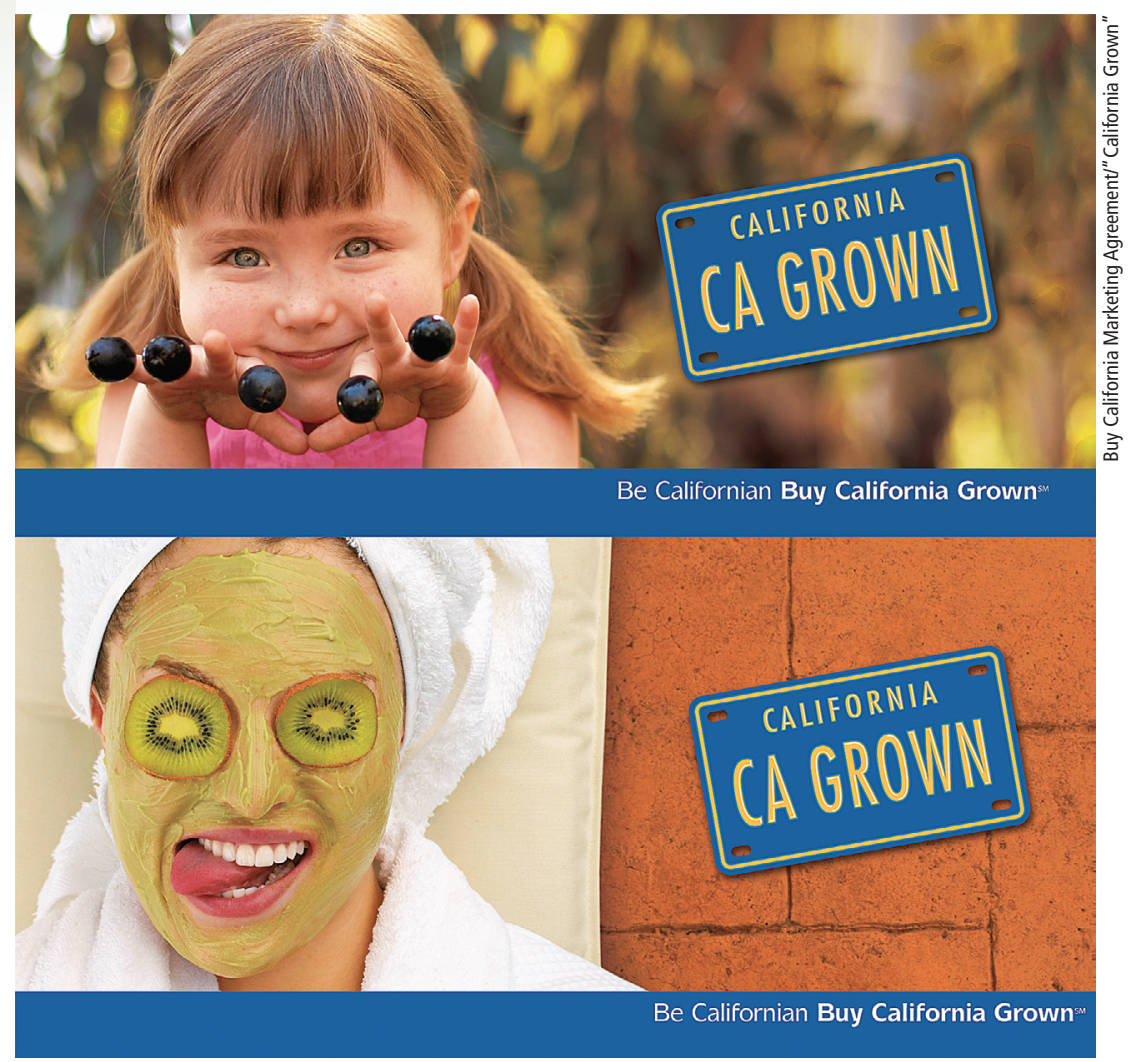

About two-thirds of California crops fall under marketing orders, in which growers pay mandatory assessments for marketing, promotion, research and quality inspection. Above, the Buy California Marketing Agreement advertises the state's crops as "California Grown"; it is supported by state and industry funds.

check-off programs, nor activities of the California Department of Food and Agriculture's (CDFA) Dairy Branch in administering and enforcing provisions of the California Milk Marketing Order.

\section{Mandated marketing programs}

In 2004, mandated marketing programs covered California commodities ranging from $96.6 \%$ of the value of fruit and nut production to $8.3 \%$ of nursery and floral production (table 1). As of June 2006, California's 63 active marketing programs included 11 federal marketing orders, 29 state marketing orders and agreements, 20 commissions, and 3 councils (see sidebar, page 178). Since then the Pistachio Commission has been terminated by an industry vote, and a California Leafy Green Products Handler Marketing Agreement has been approved to certify the safe handling, shipment and sale of leafy green products to consumers (CDFA 2007). Individual commodity mar- keting programs have been terminated, consolidated and initiated in response to changing marketing issues, with the total number increasing over time. Notable

\begin{tabular}{lccc}
\multicolumn{4}{c}{ TABLE 1. Production value for } \\
California commodities covered by \\
marketing programs as share of all \\
commodities in each crop category, 2004
\end{tabular}




\section{Mandated marketing programs supported by California producers}

Federal marketing orders for fruits, vegetables, nuts and specialty crops are authorized by the Agricultural Marketing Agreement Act of 1937, as amended. They are requested by producers to help solve marketing problems and can cover production in one or several states. A marketing order may contain provisions for one or more of the following: generic advertising and sales promotion; production, processing and marketing research; quality regulations with inspection; supply management or volume control; the standardization of containers or packs; and the prohibition of unfair trade practices. The secretary of agriculture holds public hearings on the proposed marketing order, and if it is determined to be in the public interest and likely to help solve the industry's marketing problems, it goes to a producer referendum. Two-thirds of the producers, or producers representing two-thirds of the volume produced in the proposed marketing order area, must vote to adopt the order. Once passed, an order is binding on all producers.

California marketing orders are authorized by the California Agricultural Marketing Act of 1937. They are available for a wider range of commodities and allow for more activities than federal orders. California legislation permits programs for advertising and promotion, research, the prohibition of unfair trade practices, product inspection, stabilization pools and the regulation of grades and standards. Procedures for establishing a state order are similar to a federal order, but the voting requirements differ: they must be approved by (1) $51 \%$ of the producers marketing $65 \%$ of the volume; (2) $65 \%$ of the producers marketing $51 \%$ of the volume; or (3) a minimum of $40 \%$ of producers voting, then of those voting $51 \%$ of the voting producers with $65 \%$ of the volume, or vice-versa. An order is binding on all producers.

California marketing agreements are authorized by the California Agricultural Marketing Act of 1937, with provisions similar to California marketing orders. There is no vote on a marketing agreement, since it is a signed contract between the secretary of agriculture and individual handlers of a particular commodity. Agreements are voluntary and affect only the handlers who sign.

California commodity commissions and councils are each established by a specific law passed by the state legislature and signed by the governor. While the provisions for each commission are wide open, most concentrate on advertising, promotion and research; councils tend to concentrate on education programs, promotion and research. The establishment of a commission typically requires an industry referendum, and the voting requirements are usually the same as for a marketing order. Councils have been established without an industry vote. California commodity commissions and councils have more program and budget autonomy than do marketing orders. They develop their own operating plans and budgets, with CDFA concurrence, and can hire executives and elect commission members without the CDFA's prior approval.

National check-off programs are federal programs to fund generic advertising and research activities for a particular commodity that are financed by mandatory assessments on all of the domestically marketed commodity. The name "check-off" comes from the method of collecting assessments. Producers, handlers and/or importers are required to pay an assessment, usually deducted from revenue at the time of sale. Prior to 1996, national check-off programs required that Congress pass specific legislation for each individual commodity; this procedure is still available. Then passage of the Commodity Promotion, Research, and Information Act of 1996 gave USDA broad-based authority to establish national generic promotion and research programs for nearly all commodities, either at its own initiative or upon the request of an industry group. There are currently 17 of these programs with estimated 2005 assessments of $\$ 765$ million. trends have been a decrease in the number of federal marketing orders applicable to California crops and an increase in the number of commodity commissions.

More than half of these programs have been established since 1980. In addition, 12 commodity commissions have been established since 1990, with several replacing marketing orders. While all mandated marketing programs are subject to government approval and oversight, commissions and councils tend to enjoy the most autonomy.

Mandated marketing programs can include one or more provisions for research, minimum quality standards, regulation of packaging and containers, quantity controls, and/or generic advertising and promotion. Generic, as contrasted with brand advertising and promotion, speaks to general commodity characteristics rather than referring to a specific producer, brand name or processor. The purpose of generic programs is to increase the total demand for a commodity (the size of the pie), while brand programs seek to increase market share (the slice of the pie). Federal and state marketing orders established during the 1930s and 1940s emphasized the use of supply controls to improve prices. Now the provisions that are most often used by federal programs are minimum grades and sizes, pack and container regulations, research and generic promotion. Likewise, the emphasis of state marketing orders has shifted, with more than three-quarters of California programs including provisions for generic promotion and research by 1960. In addition, California commodity commissions emphasizing promotion and research have taken the place of many state marketing orders.

\section{Commodity promotion litigation}

While producer support for promotion programs is strong, it is not unanimous, and litigation over mandatory assessments for advertising and promotion has been essentially continuous since the 1980s. The majority of lawsuits have been filed by large growers for various reasons, including philosophical opposition to government interference in marketing their products, a belief that they could obtain a better return promoting their own brand, and basic disagreements with the promotion message or operation of the program.

Three cases concerning the constitutionality of generic promotion programs 


\section{In 2004, mandated marketing programs covered California commodities ranging from $96.6 \%$ of fruits and nuts to $8.3 \%$ of nursery and floral production.}

have been heard by the U.S. Supreme Court (Kaiser et al. 2005, ch. 3). In the 1997 case of Glickman v. Wileman Bros. $\mathcal{E}$ Elliott, Inc., et al., the Supreme Court ruled that federally mandated generic advertising for California peaches, plums and nectarines did not violate the First Amendment of the U.S. Constitution. In the five-to-four ruling, the Court noted that the business entities that are compelled to fund generic advertising do so as part of a broader collective enterprise in which the freedom to act independently is already constrained by the regulatory scheme.

This ruling seemed to take much of the legal pressure off generic promotion programs, until a contrary decision was issued in 2001. In U.S. v. United Foods, the Supreme Court ruled that the national Mushroom Promotion Act of 1990 violated the First Amendment. This ruling set off a flood of litigation against other promotion programs, with lower courts striking down a number of them.

Then, in 2005 the Supreme Court agreed to hear a third promotion program case on an Eighth Circuit Court ruling that the national beef checkoff program was unconstitutional. In Livestock Marketing Association v. USDA, the Supreme Court ruled (May 23, 2005) that the national beef check-off program is constitutional. The ruling, which overturned lower court decisions, stated that the beef promotion messages were government speech that is not subject to certain First Amendment challenges. This newest ruling is expected to settle pending litigation for several generic promotion programs and increase producer interest in promotional programs. Issues still remain; for example, in 2005 Paramount Farms, California's largest pistachio producer, filed a lawsuit against the California Pistachio Commission charging that its generic promotion program is ineffective. Then in 2007, the California Pistachio Commission was terminated by a referendum vote of the growers.

\section{Program expenditures increasing}

Budgeted expenditures for California marketing programs have increased significantly over time. Lee et al. (1996) estimated total budgets of $\$ 71.35$ million in 1985 and \$112.94 million in 1992. The estimated total for 2002-2003 was just over \$208 million (Kaiser et al. 2005, ch. 2), increasing to over $\$ 226$ million for 2004-2005 (table 2C). A number of factors have contributed to the observed increase, including participation by more crops (especially vegetables), the effects of inflation, and growth in the importance of individual crops.

Tables 2A, 2B and 2C provide details on California mandated marketing programs and expenditures in the broad categories of administration, promotion, inspection and research. These are the most recent budget data available, covering annual budget periods that include months in 2004 in the case of federal marketing orders, to fiscal years that begin in 2005 and early 2006 for some state programs. Note that most programs include only the direct costs attributable to promotion, inspection or research in each of these three categories, with all other expenses (including unallocated overhead) in the administration cost category.

Overall, the 63 California programs allocated $68.1 \%$ of their total budgets for advertising and promotion, $11.0 \%$ for research, $3.9 \%$ for inspection programs and the remainder for administration. California marketing orders and agreements accounted for $44.6 \%$ of total expenditures, followed by state com- modity commissions (33.3\%), federal marketing orders (18.3\%) and councils $(3.8 \%)$.

Advertising and promotion. California commodity producer groups spent over \$154 million on generic advertising and promotion programs during 2004-2005 (table 2B). These programs ranged from high-profile TV advertising such as "Real California Cheese" and "Got Milk?" to more common media messages in magazines, newspapers, radio and billboards, and public relations campaigns.

Research has documented significant increases in product demand and prices as a result of commodity advertising and promotion programs, with the net monetary benefits to producers being much greater than costs (Kaiser et al. 2005). For example, promotions led to statistically significant increases in demand and price in case studies for eight California crops (table grapes, eggs, prunes, avocados, almonds, walnuts, raisins and strawberries) and benefit-cost estimates for four national check-off programs (dairy, beef, pork and cotton). Kaiser et al. (2005, p. 412) wrote that "the overwhelming conclusion . . . is that mandated commodity marketing programs have been very profitable for California's agricultural producers. In every case, the evidence suggests that one can be reasonably confident that the benefits have well exceeded the costs and that it would

\begin{tabular}{|c|c|c|c|c|c|}
\hline \multirow[b]{2}{*}{ Federal marketing order } & \multirow[b]{2}{*}{ Administration } & \multirow[b]{2}{*}{ Promotion } & \multirow[b]{2}{*}{ Inspection } & \multirow[b]{2}{*}{ Research } & \multirow[b]{2}{*}{ Budgeted total } \\
\hline & & & & & \\
\hline & $\ldots \ldots \ldots \ldots$ & $\ldots \ldots \ldots$ & $\ldots \$ \ldots$ & $\ldots \ldots \ldots$ & $\ldots \ldots \ldots \ldots$ \\
\hline Almonds & $5,550,023$ & $16,330,000$ & & $2,147,321$ & $24,027,344$ \\
\hline Dates & 110,501 & 112,499 & & & 223,000 \\
\hline Grapes-California desert & 88,091 & & & 100,000 & 188,091 \\
\hline Kiwifruit & 88,859 & & & & 88,859 \\
\hline Nectarines & 638,770 & $3,161,852$ & $1,153,676$ & 208,568 & $5,162,866$ \\
\hline Olives & 360,563 & 633,500 & & 275,000 & $1,269,063$ \\
\hline Peaches (fresh) & 540,455 & $3,188,457$ & $1,240,520$ & 208,570 & $5,178,002$ \\
\hline Pistachios & 271,499 & & & & 271,499 \\
\hline Plums (dried) & 275,800 & & & & 275,800 \\
\hline Raisins & $2,200,000$ & & & & $2,200,000$ \\
\hline Walnuts & 712,000 & $1,393,500$ & & 644,000 & $2,749,500$ \\
\hline Subtotal & $10,836,561$ & $24,819,808$ & $2,394,196$ & $3,583,459$ & $41,634,024$ \\
\hline
\end{tabular}


TABLE 2B. State marketing orders and agreements for California commodities, budgeted expenditures by category, 2004-2005

\begin{tabular}{|c|c|c|c|c|c|}
\hline California marketing order & Administration & Promotion & Inspection & Research & Budgeted total \\
\hline & & & $\ldots \$$ & 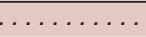 & $\ldots \ldots \ldots \ldots \ldots$ \\
\hline Alfalfa seed production & 25,620 & & & 28,430 & 54,050 \\
\hline Artichoke promotion & 54,000 & 3,800 & & 240,000 & 297,800 \\
\hline Buy California Market. Agree. & & 522,500 & & & \\
\hline Cantaloupe & 70,240 & 33,500 & 149,434 & & 253,174 \\
\hline Carrots (fresh) & 84,900 & 148,000 & & 375,000 & 607,900 \\
\hline Celery & 63,950 & & & 207,717 & 271,667 \\
\hline Cherry & 263,900 & $1,731,018$ & & 129,731 & $2,124,649$ \\
\hline Citrus nursery & 75,000 & & & 95,000 & 170,000 \\
\hline Citrus research & 708,300 & & & $3,280,147$ & $3,988,447$ \\
\hline Dry beans & 129,050 & 130,500 & 0 & 135,250 & 394,800 \\
\hline Figs (dried) & 478,558 & 427,929 & 0 & 116,902 & $1,023,389$ \\
\hline Garlic and onion dehydrator & 211,636 & & 229,272 & & 440,908 \\
\hline Garlic and onion research & 93,900 & & & 100,000 & 193,900 \\
\hline Iceberg lettuce research & 278,051 & 0 & & 550,750 & 828,801 \\
\hline Melon research & 61,970 & & & 165,954 & 227,924 \\
\hline Manufacturing milk & 98,500 & $1,307,500$ & & 0 & $1,406,000$ \\
\hline Market milk & $2,093,000$ & $35,692,000$ & & $3,340,000$ & $41,125,000$ \\
\hline Milk (fluid) & 885,000 & $19,170,324$ & & & $20,055,324$ \\
\hline Peaches (cling) & 158,800 & $1,620,000$ & & 280,000 & $2,058,800$ \\
\hline Pears & 215,404 & $1,334,593$ & & 187,746 & $1,737,743$ \\
\hline Plums & 736,955 & $1,546,283$ & 800,715 & 111,718 & $3,195,671$ \\
\hline Plums (dried) & 790,065 & $3,685,000$ & & 438,000 & $4,913,065$ \\
\hline Potato research & 53,150 & & & 57,000 & 110,150 \\
\hline Raisins & $1,222,000$ & $4,479,500$ & & 607,000 & $6,308,500$ \\
\hline Rice research & 192,500 & & & $2,416,361$ & $2,608,861$ \\
\hline Strawberry (processing) & 438,300 & & 481,800 & & 920,100 \\
\hline Tomato (processing) & 180,000 & & $3,540,204$ & 40,000 & $3,760,204$ \\
\hline Wild rice & 27,660 & 56,805 & & 20,299 & 104,764 \\
\hline Winegrape insp. agreement & 103,500 & & $1,199,723$ & 135,000 & $1,438,223$ \\
\hline Subtotal & $10,316,409$ & $71,366,752$ & $6,401,148$ & $13,058,005$ & $101,142,314$ \\
\hline
\end{tabular}

TABLE 2C. California commodity commissions and councils, budgeted expenditures, 2004-2005

\begin{tabular}{|c|c|c|c|c|c|}
\hline Commissions & Administration & Promotion & Inspection & Research & Budgeted total \\
\hline & $\ldots \ldots \ldots \ldots$ & $\ldots \ldots \ldots$ & $\ldots \ldots \ldots$ & $\ldots \ldots \ldots$ & $\ldots \ldots \ldots \ldots$ \\
\hline Apple & 335,175 & 178,500 & & 41,500 & 555,175 \\
\hline Asparagus & 161,200 & 492,746 & & 122,476 & 776,422 \\
\hline Avocado & $4,418,500$ & $12,984,200$ & & $2,072,500$ & $19,475,200$ \\
\hline Date & 28,189 & 0 & & 18,653 & 46,842 \\
\hline Flower (cut) & 191,009 & 939,865 & & 115,118 & $1,245,992$ \\
\hline Forest products & 203,671 & $1,401,396$ & & & $1,605,067$ \\
\hline Grape rootstock & 58,217 & & & 184,625 & 242,842 \\
\hline Grape-table & $3,155,000$ & $10,241,871$ & & 657,289 & $14,054,160$ \\
\hline Kiwifruit & 154,480 & 215,008 & & 30,900 & 400,388 \\
\hline Pepper & 62,310 & & & 132,750 & 195,060 \\
\hline Pistachio & $1,678,145$ & $5,764,362$ & & 615,000 & $8,057,507$ \\
\hline Rice & $2,664,585$ & 795,500 & & 130,000 & $3,590,085$ \\
\hline Sea urchin & 110,000 & & & & 110,000 \\
\hline Sheep & 72,700 & 89,875 & & 19,844 & 182,419 \\
\hline Strawberry (fresh) & $1,242,128$ & $5,935,621$ & & $2,269,672$ & $9,447,421$ \\
\hline Tomato & 532,790 & $1,415,790$ & & 417,027 & $2,365,607$ \\
\hline Walnut & 802,500 & $9,247,500$ & & 990,000 & $11,040,000$ \\
\hline Wheat & 313,737 & 155,500 & & 186,889 & 656,126 \\
\hline Winegrape, Lake County & 64,655 & 148,022 & & 54,565 & 267,242 \\
\hline Winegrape, Lodi-Woodbridge & 224,176 & 674,350 & & 185,119 & $1,083,645$ \\
\hline Subtotal & $16,473,167$ & $50,680,106$ & & $8,243,927$ & $75,397,200$ \\
\hline Beef council & 636,100 & $1,344,500$ & & 0 & $1,980,600$ \\
\hline Dairy council & 560,224 & $5,672,103$ & & 155,500 & $6,387,827$ \\
\hline Salmon council & 61,400 & 121,135 & & 0 & 182,535 \\
\hline Subtotal & $1,257,724$ & $7,137,738$ & & 155,500 & $8,550,962$ \\
\hline Total: Tables $2 \mathrm{~A}+2 \mathrm{~B}+2 \mathrm{C}$ & $38,883,861$ & $154,004,404$ & $8,795,344$ & $25,040,891$ & $226,724,500$ \\
\hline
\end{tabular}

have been profitable for producers to have increased expenditures on the programs."

Tables 2A, 2B and 2C do not include all funding for California commodity promotion or assessments paid by California producers. For example, USDA's Market Access Program awarded $\$ 23.95$ million (out of total grants of $\$ 140$ million nationwide) to California trade organizations and marketing programs in 2005. These federal dollar-for-dollar matching funds are used for market development activities in export markets. California producers also contribute to the majority of the 17 national check-off promotion programs, including those for blueberries, beef, cotton, dairy, eggs, fluid milk, honey, lamb, mushrooms, pork, potatoes and watermelons. None of the assessments for national check-off programs, which totaled an estimated $\$ 765$ million for all U.S. producers for 2005 (Becker 2007), are included in tables 2A and 2B.

Research. There were 28 California programs with research expenditures totaling almost $\$ 8.5$ million in 1992 (Lee et al. 1996, p. 26); this increased to 45 programs with expenditures of over \$21.2 million in 2003-2004 (Kaiser et al. 2005, ch. 2), and further to 48 programs with expenditures over $\$ 25$ million in 2004-2005 (tables 2A and 2B). The share of total program expenditures dedicated to research increased from about 7.5\% in 1992 to about $11 \%$ in 2004-2005.

Historically, research funded by California marketing programs was focused on production problems and issues. A sampling of research topics includes new variety development, insect and pest management, irrigation and water management, disease control, pollination, harvest methods/machinery, crop management and postharvest quality control. More recently, California marketing programs have also funded nutrition and health research.

There are numerous examples of the benefits to producers from research expenditures by mandated marketing programs. Research has resulted in cost savings from the reduced use of inputs (water, pesticides and fertilizer) and changes in the input mix, yield increases, reductions in postharvest losses, improved crop characteristics and new management techniques. 
Several California commodity groups have funded research at UC that has helped them become the most efficient producers in the United States and world. Included are almonds, walnuts, pistachios, strawberries, lettuce and grapes (Alston and Zilberman 1998). California producers have gained a short- to intermediate-term competitive edge from these research-enabling improvements and, over time, benefits have flowed to consumers in the form of increased supply and availability, improved quality and lower prices.

Minimum quality standards. The purpose of minimum quality standards is to maintain or enhance demand for a commodity by keeping inferior products off the market. They are used to prevent a market failure known as the "lemons" problem, which occurs when a product has unobservable characteristics for which the seller has much better information than the buyer. The best example is early-season sales of immature fruit, which can look good but taste sour. While the individual producer obtains a high price for this fruit, consumer dissatisfaction can adversely affect prices and subsequent sales of high-quality product by other producers later in the season.

Provisions for grades and minimum quality standards are included in all 11 current federal marketing orders for California fruits, vegetables and nuts. However, only 11 of the 29 California state marketing orders and agreements include quality standards and inspection provisions, and just seven of them actively use the provisions. Minimum quality standards typically include a minimum size, to keep small product off the market. Depending on the commodity, they may also specify minimum sweetness (kiwifruit), a minimum degree of maturity (nectarines and peaches), acceptable color and/or amount of discoloration, shape, amount of insect damage or cosmetic defects allowable, and maximum mechanical damage such as bruises, cuts or missing stems.

While empirical analyses of the economic impact of such standards are limited, those available indicate that it is probably relatively small (GAO 1985). However, some minimum quality standards have been controversial, with

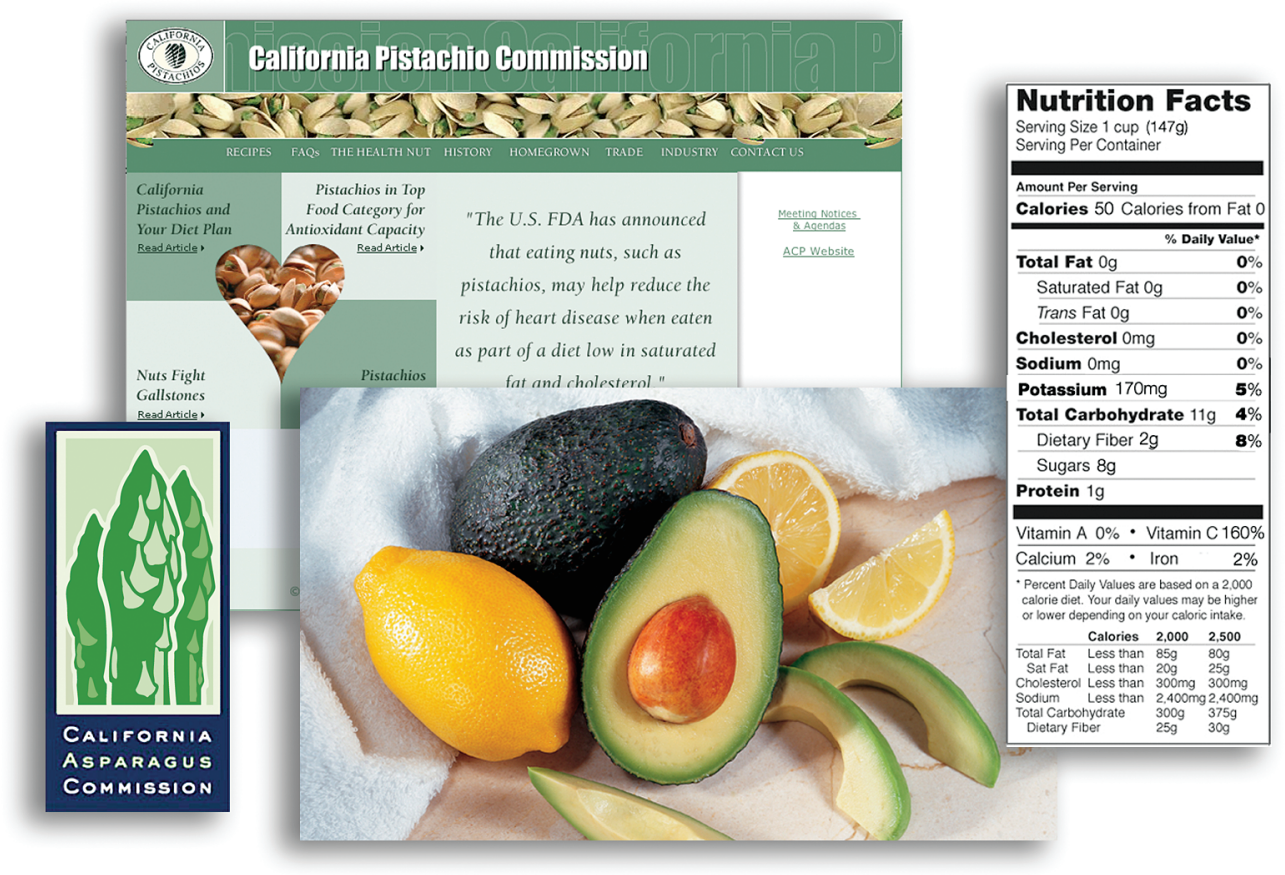

In California, some marketing programs have begun promoting the health benefits of crops such as pistachios and avocados, or providing nutrition facts (strawberries) and recipes (asparagus).

charges that they: (1) are an inefficient form of supply control because they divert product to nonfood uses such as animal feed; (2) are de facto price discrimination because they divert product to the less-price-sensitive processing market outlet; (3) waste edible fruit with the primary impact being on the poorest consumers; and (4) are sometimes inequitable because of regional variations in production conditions.

Supply controls. A group that controls all or most production of a commodity can gain a measure of monopoly power and enhance short-run returns through restricting the supply placed on the market or practicing price discrimination between markets. However, such monopoly pricing reduces consumer welfare by increasing prices for a smaller amount of product and distorts resource allocation decisions, while producers face all of the problems of maintaining a cartel.

A key feature of marketing orders is that volume controls apply only to the quantity placed on the market — they do not control the amount of product produced. Thus, reduced risk from price stabilization and improved average returns from effective price discrimination can be expected to shift the long-run supply curve to the right, increasing production of the marketing order commodity and increasing required product diversions. Over time, producers discover that they are subject to onerous controls and that returns are no better than before the program.

The use of quantity (supply) control provisions has decreased significantly over time as longer-run economic impacts and administrative problems became evident. Six federal marketing orders for California commodities and two state marketing orders have quantity control provisions but, among these eight, only the federal marketing order for raisins has used these provisions during the last 5 years. In addition, government approval of a new marketing program with supply control provisions is now difficult to obtain.

\section{Food safety efforts}

Assuring food safety is the newest use of minimum quality standards and inspection in marketing programs. The purpose of these standards is to enhance product demand by reducing the chances of a food safety incident, thereby increasing consumer confidence and preventing the costs of product recall or rejection. There are three California marketing programs currently stressing food safety: the Leafy Greens Products Handler Marketing Agreement, and the federal marketing orders for pistachios and almonds.

The main provisions of the federal marketing order for pistachios set standards and require testing for quality and aflatoxin, a cancer-causing mold that can contaminate many nuts and 
grains. Producers' concerns about the possible negative effects of an aflatoxin poisoning event were the major factor leading to the creation and adoption of the marketing order for pistachios, with support by more than $90 \%$ of the growers in a 2004 vote (Gray et al. 2005).

Similarly, the California almond industry is currently developing treatment standards and plans for the pasteurization of all raw, natural almonds as a result of two similar food safety events. In 2001, a Salmonella outbreak in Canada was traced back to raw almonds from three orchards in California. Then in spring 2004, foodborne illnesses in Oregon from Salmonella were traced to raw almonds purchased from a retailer who obtained all supplies from one handler. The handler initiated a voluntary recall that involved approximately 15 million pounds of almonds.

The California almond industry determined that additional steps were required to ensure that a third such incident does not occur. In summer 2004, the Almond Board of California's board of directors unanimously approved an action plan calling for the pasteurization of $100 \%$ raw, natural almonds entering the food distribution system. The proposed new quality standard submitted to USDA will be effective when it has been determined that pasteurization technologies and capacity are sufficient to process all California production. The almond board's target dates for voluntary implementation are during the 2006-2007 production/marketing year, with mandatory implementation for all North American shipments on Aug. 1, 2007, and mandatory implementation for $100 \%$ of almond shipments, including exports, on Aug. 1, 2008.

\section{Health and nutrition research}

Several California commodity groups are funding health and nutrition research on their products and using promotion programs to disseminate the results. During the last 5 years, more than \$8.1 million was spent on research concerning the health and nutrition benefits of almonds, avocados, strawberries and walnuts; these four commodity groups also spent more than \$19 million during the 2004-2005 marketing year on promotion using nutrition/health messages. Other commodity groups funding such programs include apples, blueberries, cranberries, kiwifruit, milk and table grapes.

In 1990, the California Walnut

Commission became the first Californiamandated marketing program to specifically fund health and nutrition research, when it contracted with Loma Linda University for research on the protective effects of walnut consumption on the risk of coronary heart disease. The motivation for walnut nutrition research was to counter the popular perception that walnut consumption was unhealthy because of their high oil content. Likewise, the Almond Board of California initiated a Nutrition Research Program and established a Nutrition Subcommittee in 1995. In 1997, the California Avocado Commission made a strategic change to proactively communicate the nutritional benefits of avocados through national public relations and outreach efforts. In 2003, the California Strawberry Commission began funding nutrition research proposals. This research has already yielded results that are being used in strawberry advertising and promotion.

These four commodities each have developed analyses detailing their chemical and nutritional composition, including the amount and type of fat, calories, vitamins, phytochemicals, antioxidants and minerals. The presence of particular components, already associated with favorable health outcomes, has helped focus research on important health topics. Each commodity group has or is seeking evidence that consuming their product may reduce the risk of heart disease and all have evidence that product components may help to lower the risk of certain cancers. In addition, each of the commodities contains antioxidants known to slow the aging process and protect against heart disease and various forms of cancer. Almonds, avocados and walnuts can be a component of diets to control weight gain and each can be part of a healthy diet for managing and controlling diabetes (see www. almondsarein.com and www.walnuts. org/health/professionals/index.php).

The walnut industry submitted its research results for a heart health claim to the U.S. Food and Drug Administration (FDA), and the almond industry submitted its as part of a petition filed by the International Tree Nut Council Nutrition Research and Education Foundation to the FDA for a heart health claim for nuts. (Walnuts were also included in the International Tree Nut Council petition.) The FDA approved a qualified health claim for walnuts, and another for almonds and other selected nuts, on July 15, 2003, which states: "Scientific evidence suggests but does not prove that eating 1.5 ounces per day of (specify nut) as part of a diet low in saturated fat and cholesterol may reduce the risk of heart disease."

\section{Promoting health benefits}

Each of these four commodity groups has used news releases and public relations to publicize the nutrition and health benefits of their products. The messages for walnuts and avocados have been communicated almost entirely through third parties such as magazines, newspapers, doctors, nutritionists or other credible sources, rather than paid advertising. The advertising emphasis for walnuts and avocados has been on quality, taste and recipes.

The Almond Board of California initially relied on public relations to disseminate its message on the health and nutritional benefits of almonds. Following FDA approval of their qualified health claim, their research results were incorporated into paid advertising and promotion, almost always featuring a health message. Likewise, in 2003 the California Strawberry Commission introduced a promotion campaign called "Be Well - Get the Red Edge" (Kaiser et al. 2005), which targets health and nutrition professionals, and consumer and trade media.

Commodity groups have found that they can stretch their promotion budgets by partnering with other groups. After FDA approval of the qualified heart health claim for nuts, the Almond Board of California partnered with the American Heart Association (AHA) and now makes liberal use of the AHA logo in almond advertising. The California Walnut Commission formed 
a partnership with the Spanish Heart Foundation, and distributed more than 40,000 brochures and samples during "Heart Week" in Spain. The foundation also includes recipes and other information concerning California walnuts on its Web site. The California Avocado Commission is also leveraging its research results by partnering with health organizations, including the American Diabetes Association, UCLA Nutrition Education, American Association of Diabetes Educators, American Dietetic Association and IDEA Health and Fitness Association.

\section{Including imports in marketing}

Imports can easily create a "free rider" problem for U.S. commodity programs. California avocado producers spent more than $\$ 182$ million on market development between 1961 and 2003 (Carman 2006). They were understandably upset to see producers in other countries taking advantage of state promotional efforts when the national market share of imported avocadoes increased from less than 3\% prior to 1990 to about 34\% from 1998 through 2002. With the 2002 passage of the Hass Avocado Promotion and Research Order (HAPO), all Hass avocados sold in the United States, including imports, are assessed 2.5 cents per pound to fund advertising, promotion, research and data dissemination. Increased avocado demand due to HAPO promotion will offset much of the price impact of increased imports, and importers should enjoy attractive returns from their promotion dollars. Carman (2006, p. 476) estimated that returns for importers' spending on advertising and promotion ranged from $\$ 2.09$ to $\$ 6.31$ per dollar spent, depending on the level of imports and the effectiveness of Hass avocado advertising.

\section{Information programs}

An important and often overlooked benefit of mandated marketing programs, in addition to having an organized commodity group, is the value of the information they gather, organize and disseminate. A first-of-its-kind innovation for commodity groups was the establishment, by the Hass Avocado Board (HAB), of a Web-based program (www.avohq.com) designed to exchange crop and marketing information among 100 packers and over 20,000 producers from the five HAB members California, Chile, Dominican Republic, Mexico and New Zealand.

The HAB Web site notes: "The program goal is to develop collaborative strategies to achieve an orderly flow of the 750 million pounds of fruit sent annually into the U.S. marketplace." This Web-based program collects, tracks, analyzes and disseminates information relevant to selling Hass avocados in the U.S. market. It provides all players in the U.S. market with 24-hour access to critical market data that drives decisions about growing, shipping, distribution and marketing.

The HAB market information program is an exciting development in produce marketing, made possible by recent worldwide developments in communication networks. It provides a dramatic reversal of trends that have reduced the availability and timeliness of market and price information for produce markets. The widespread availability of marketing information and data is a theoretical requirement for competitive markets. It will be interesting to see to what degree improvements in marketing efficiency made possible through HAB flow to producers funding the program. If successful, the program template can be extended to other commodities and countries, with

\section{References}

Alston JA, Zilberman D. 1998. Science and Technology in California Agriculture. UC Agricultural Issues Center, Issues Brief No 4. http://aic.ucdavis.edu/pub/ briefs/brief4.html.

Becker GS. 2007. Federal Farm Promotion ("Check-Off") Programs. Library of Congress, Congressional Research Service. Order Code 95-353, updated April 17, 2007.

Carman HF. 2006. Offsetting price impacts from imports with generic advertising and promotion programs: The Hass Avocado Promotion and Research Order. Rev Ag Econ 28(4):463-81.

[CDFA] California Department of Food and Agriculture. 2007. California Leafy Green Products Handler Marketing Agreement. Marketing Branch. Sacramento, Feb 10. www.caleafygreens.ca.gov.

[GAO] US General Accounting Office. 1985. The Role of Marketing Orders in Establishing and Maintaining Orderly Marketing. Comptroller General, Washington, DC. GAO/RCED-85-57, July 31.

Gray RS, Sumner DA, Alston JM, et al. 2005. Economic Consequences of Mandated Grading and Food Safety Assurance: Ex Ante Analysis of the Fed- benefits flowing to producers and consumers worldwide.

\section{Marketing program trends}

California farmers continue to rely on mandated marketing programs for solutions to their marketing problems and as a competitive tool to improve crop returns through demand expansion programs. Forward-looking producer boards appear to be emphasizing customer satisfaction in designing action programs. New commodity research programs on health and nutrition are providing information desired by health-conscious consumers, which is also effective for promotion activities. Mandatory food-safety programs for pistachios and almonds offer benefits to both producers and consumers. Finally, the market information program initiated by $\mathrm{HAB}$ is an innovative development based on the latest information technology, which is designed to increase marketing efficiency by smoothing the flow of avocados through the distribution network to retail customers. If this program is successful, the model has the potential to be extended to other commodities and countries, with benefits flowing to producers and consumers worldwide.

H. Carman is Professor Emeritus of Agricultural and Resource Economics, UC Davis.

eral Marketing Order for California Pistachios. Giannini Foundation Monograph No 46. UC DANR, Berkeley, CA. 60 p. www.agecon.ucdavis.edu.

Kaiser HM, Alston JM, Crespi JM, Sexton RJ 2005. The Economics of Commodity Promotion Programs: Lessons from California. New York: Peter Lang Pub. 428 p.

Lee H, Alston JM, Carman HF, Sutton W. 1996. Mandated Marketing Programs for California Commodities. Giannini Foundation Info Ser No 96-1, p 26. UC DANR, Berkeley, CA. www. agecon.ucdavis.edu.

[USDA-AMS] US Department of Agriculture Agricultural Marketing Service. 2007. Fruit and Vegetable Programs Web site. www.ams.usda. gov/fv/moab.html (accessed June 6, 2007).

[USDA-NASS] USDA National Agricultural Statistics Service. 2005. California Agricultural Statistics, 2004. October 2005. California Field Office, Sacramento, CA. Www.nass.usda.gov/ Statistics_by_State/California/Publications/ California_Ag_Statistics/index_casbultn.asp (accessed June 6, 2007). 